\title{
Accessibility Residence of Disabled People to the Health Unit
}

\section{Acessibilidade de Pessoas com Deficiência da Residência à Unidade de Saúde da Família}

\author{
Vagner Ferreira do Nascimento*a, Rosangela Aparecida Gonçalves ${ }^{\mathrm{b}}$; Walber Gineli de Jesus ; \\ Bianca Carvalho da Graça ${ }^{a}$;Ana Cláudia Pereira Terças-Trettel ${ }^{\text {d; }}$ Thalise Yuri Hattori ${ }^{a}$ \\ anniversity of the state of Mato Grosso, Graduate Program in Nursing. \\ bUniversity of the State of Mato Grosso. Municipal Hospital in Tangará da Serra. \\ 'University of the State of Mato Grosso, Nursing Department. Hospital das Clínicas de Tangará da Serra. \\ dUniversity of the state of Mato Grosso, Collective Health Graduate Program. \\ *E-mail: vagnerschon@hotmail.com \\ Recebido em: 07/02/19 \\ Aprovado em: 01/07/19
}

\begin{abstract}
The objective of the study was to know the accessibility of people with disabilities to the family health unit. This is an observational, descriptive study with a qualitative approach. Made in suburban neighborhoods in the largest municipality in the northern region of Mato Grosso. Data collection took place in March 2016, through an observation script and measuring instruments. The images were interpreted by iconographic analysis. It has been verified that the route of the residence of the disabled to the health unit, has many obstacles that can make the circulation unfeasible. This fact gives these people the tendency to lose their autonomy, since there will be the need of third parties help. Thus, they end up risking amid urban imperfections and irregularities and this trend to entail new possibilities of damages. They can also opt for other routes with fewer barriers, but more distant and dangerous. It is undeniable that the best way to reduce barriers is the movement of social inclusion, particularly in the planning of buildings and public mobility with greater accessibility, in the knowledge / reflection of the needs of the disabled person, support to families and articulation with the present social devices in the community. In addition, health professionals, especially nurses, play a key role in establishing links, so they can devise strategies to minimize such obstacles, while at the same time relieving moments of anguish and pain.
\end{abstract}

Keywords: Health Services Accessibility. Disabled Persons. Architectural Accessibility.

\section{Resumo}

O objetivo do estudo foi conhecer a acessibilidade de pessoas com deficiência da residência à unidade de saúde da família. Trata-se de estudo observacional, descritivo e com abordagem qualitativa. Realizado em bairros de periferia no maior município da região médio norte de Mato Grosso. A coleta de dados ocorreu em março de 2016, mediante roteiro de observação e instrumentos de medição. As imagens foram interpretadas pela análise iconográfica. Verificou-se que o percurso da residência das pessoas com deficiência à unidade de saúde, possui muitos obstáculos que podem inviabilizar a circulação. Esse fato propicia à essas pessoas tendência a perder sua autonomia, visto que, haverá necessidade do auxilio de terceiros ajuda. Assim, acabam se arriscando em meio as imperfeições e irregularidades urbanísticas e isso tende a acarretar novas possibilidades de danos. Podem ainda, optar por outros trajetos com menos barreiras, porém mais distantes e perigosos. $E$ inegável que a melhor forma de redução das barreiras seja o movimento de inclusão social, particularmente no planejamento de edificações e mobilidade pública com maior acessibilidade, no conhecimento/reflexão das necessidades da pessoa com deficiência, apoio às familias e articulação com os dispositivos sociais presentes na comunidade. Além disso, o profissional de saúde, em especial os enfermeiros, possuem papel fundamental no estabelecimento de vínculos, logo podendo traçar estratégias para minimizar tais obstáculos, e ao mesmo tempo aliviar momentos de angústia e dor.

Palavras-chave: Acesso aos Serviços de Saúde. Pessoas com Deficiência. Estruturas de Acesso.

\section{Introduction}

Currently, people with disabilities (PcD) have legal protection through the Federal Law no. 13.146, which in its first article clarifies and determines the inclusion in all social sectors, ensuring and promoting, also to other citizens, the exercise of rights and freedom. In addition, it is worth noting that this law establishes the conception and realization of projects that make the physical environment, information and communication, equipment, transport and facilities, be open to society and have accessibility for the $\mathrm{PcD}^{1.2}$.

In addition to the human values, the existence of rights guaranteed by law, requires a greater attention from the
Society for the environments and collective spaces, which may influence the quality of life of this public ${ }^{3.4}$. Once, the obstacles faced by this clientele are notorious, since their leaving their homes, enhancing feelings of helplessness and inability ${ }^{4.5}$.

However, this issue is not exclusively by their physical limitation, but, due to the inaccessibility to which are faced in some urban models. In the context of health assistance, these difficulties become even more evident, because the lack of specifics on tracks and paths, hinder the displacement and arrive to the health units ${ }^{6}$.

Some of these barriers are present in the lives of people 
with disabilities, among which we can mention: pattern of ladders, steps, holes, non-adapted toilets, slippery floors, absence of sidewalks and/or offering obstacles, vegetation in inappropriate places, lack of handrail on stairs, steep slopes, among others ${ }^{3}$.

All these hindrances end up marginalizing them causing the possibility of access to be underestimated or take a secondary role. Due to the above mentioned, the objective of the study was to know the accessibility of people with disabilities to the family health unit.

\section{Material and Methods}

This is an observational, descriptive study with a qualitative approach. Made in suburban neighborhoods in the largest municipality in the northern region of Mato Grosso state. The choice of this municipality was due to being a benchmark of 21 municipalities in Mato Grosso, having the largest population of quantitative region and by the scarcity of studies of this on-site nature.

As inclusion criteria, eripheral neighborhoods were used that adopted USF, with a population of more than 4,000 people. As an exclusion criterion neighborhood discovered by USF were established.

First, prior to data collection, there was contact and meeting with the family health teams from the areas chosen, in order to present the study and respond to the challenges ahead for their development. Afterwards, it was found the availability of a community health agent ( $\mathrm{CHA}$ ) to present the coverage area of the health unit, indicating the main routes of PcD.

In this study, the mapped routes referred to PcD who had physical disabilities from sequelae of accidents, complications (Stroke) or neurological disease.

The data were collected in March 2016, by observation script of neighborhoods and use of photographs of the main path of the residences of the subjects until the family health unit of area through digital camera Sony Cyber-shot DSC-H100 16.1mp; measuring tape graduated in centimeters by serving as a resource for the measurement of surfaces; free application of GPS for location/geotagging calculating the distance and field diary.

Even though there has been no contact with the PcD of this locality, to preserve the anonymity and confidentiality of the residences of subjects, the coding of the alphanumeric type was used, where the letter $\mathrm{S}$ indicates the subject and the numeric element that composed the assembly, the order in which the same occupies in the research.

Among the images captured of the different obstacles in the path of the $\mathrm{PcD}$ to the health unit, photographs that best represented the obstacles encountered were selected. The images were treated by conceptual analysis in three steps of interpretation: the pre-iconographic (primary level or natural), iconographic itself (secondary or conventional) and the third level, deeper, centered on the intrinsic meaning (or content), which involves an overpayment of symbolic values ${ }^{7}$.

Respecting all ethical aspects in research of environmental character, all images of the study, presented only geographical aspects and urban planning, not bringing any injury and/or damage to humans, as well as to the nature.

\section{Results and Discussion}

The region of the outskirts, where the study was carried out, is located at 5100 meters away from the downtown area $\mathrm{f}$ the municipality covers an average population of 3846 people, being a large part lacking and bolstered by government aid programs, residents in houses of masonry, with electric energy and supply of treated water, garbage collection on three separate days of the week, predominating the use of septic tank as weep hole. The collective transport flows in the region every 60 minutes.

Table 1 - Distance of the residences from the PcD to USF. March 2016. Tangará da Serra, Mato Grosso State, Brazil

\begin{tabular}{|c|c|c|}
\hline Disabled people. & Sex & Distance (meters) \\
\hline S1 & F & 899 \\
\hline S2 & M & 908 \\
\hline S3 & M & 827 \\
\hline S4 & F & 806 \\
\hline S5 & M & 790 \\
\hline S6 & M & 696 \\
\hline S7 & M & 1137 \\
\hline S8 & F & 812 \\
\hline S9 & M & 902 \\
\hline S10 & M & 572 \\
\hline S11 & M & 632 \\
\hline S12 & M & 1167 \\
\hline S13 & F & 781 \\
\hline S14 & F & 576 \\
\hline S15 & M & 242 \\
\hline S16 & M & 386 \\
\hline S17 & F & 1184 \\
\hline S18 & M & 2542 \\
\hline S19 & F & 342 \\
\hline Resch & & \\
\hline & & \\
\hline Sata & & \\
\hline & & \\
\hline & & \\
\hline & & \\
\hline
\end{tabular}

Source: Research Data.

It should be noted that the minimum distance travelled by the PcD to USF is 242 meters (S15) and the maximum, 2542 meters (S18), with an average of 852 meters.

The distribution of health units in the territory is not always in accordance with the knowledge of the geography of health, not corresponding to the ideal for the coverage of an area. So, as a result of territorialisation in health little effective, there are difficulties in the access of the population ${ }^{8}$.

In line with the difficulty in access for the account of the disposition of the USF in the territory are the obstacles encountered on the path, as the holes, gaps, downgrades from the curb and similar ${ }^{9}$. However, these setbacks are not only present in the path to the health service, within these units there is wealth of these disparities, being highlighted irregular 
floors, non-adapted toilets, high steps and similar ${ }^{10}$.

The incorporation of professionals, especially nurses in engineering teams in all constructions of health, whether public or private, tends to alleviate such disharmony in the ambience of the institutions, by prudent, cautious and look before the holistic ergonomic standards that provide security and comfort ${ }^{10}$.

Another strategy to mitigate these obstacles is to try to understand the pathology and emotional situation of these people, as well as their communicational difficulties. For this reason, the nurse must have the resources and skills, since the qualified listening to the organization of assistance, which would facilitate the comprehensiveness of health care ${ }^{11}$.

This concern is shared by professionals from other countries, such as in the United States and the United Kingdom, through debates about the accessibility and implementation of proposals and actions, such as the Network of European concept of accessibility (EuCAN), aiming at the independence of $\mathrm{PcD}$ and its insertion in the spaces along to other people ${ }^{12}$.

However, such concerns are far from the Brazilian reality, especially in the inland municipalities and peripheries, as pointed out in the study.

Figure 1 - Construction materials in the path of the residence from S8 to USF. March 2016. Tangará da Serra, Mato Grosso State, Brazil

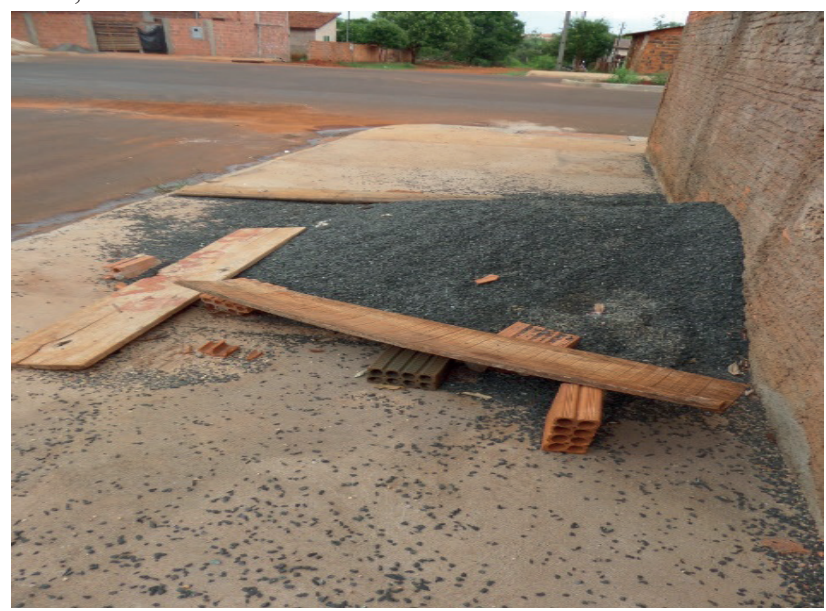

Source: The authors.

In Figure 1, it is possible to observe that the sidewalk is in appropriate size - 2.77 meters (ideal: minimum of 1.20 meters in width and 2.10 meters in height $)^{2}$, being well wide, but there is the storage of materials of construction, preventing the passage, either due to lack of space for their movement and/or the presence of scattered boulders, which can cause accidents.

In the routes travelled by $\mathrm{S} 4, \mathrm{~S} 6, \mathrm{~S} 8, \mathrm{~S} 12$ and $\mathrm{S} 15$, it was verified the scenario illustrated in Figure 1. This reality is not only limited to the region of study, but also to other Brazilian localities, as evidenced in the study conducted in Goiânia $(\mathrm{GO})^{13}$, where hindrances were observed in the routes of $\mathrm{PcD}$, as debris from civil constructions and organic waste arising from cleaning of gardens.
In a study conducted in Caratinga $(\mathrm{MG})^{14}$, it was identified as one of the main findings of the survey, in addition to debris, the presence of vendors and the buckets on the sidewalks. In the investigation of Rodrigues ${ }^{15}$ in Formiga (MG), these barriers are confirmed, in addition to statues, stalls of vendors and litters deposited incorrectly by traders.

Corroborating also with the findings in the study by Martins $^{9}$ developed in João Pessoa (PB), revealed that in the path home - health institution there are major obstacles, among them, materials into disuse and furniture of establishments; absence of crosswalk; sidewalks with measuring less than 1.20 meters and inadequate curb lowering.

Figure 2 - Barriers and absence of sidewalk paving the path from S1 to the USF. March 2016. Tangará da Serra, Mato Grosso State, Brazil

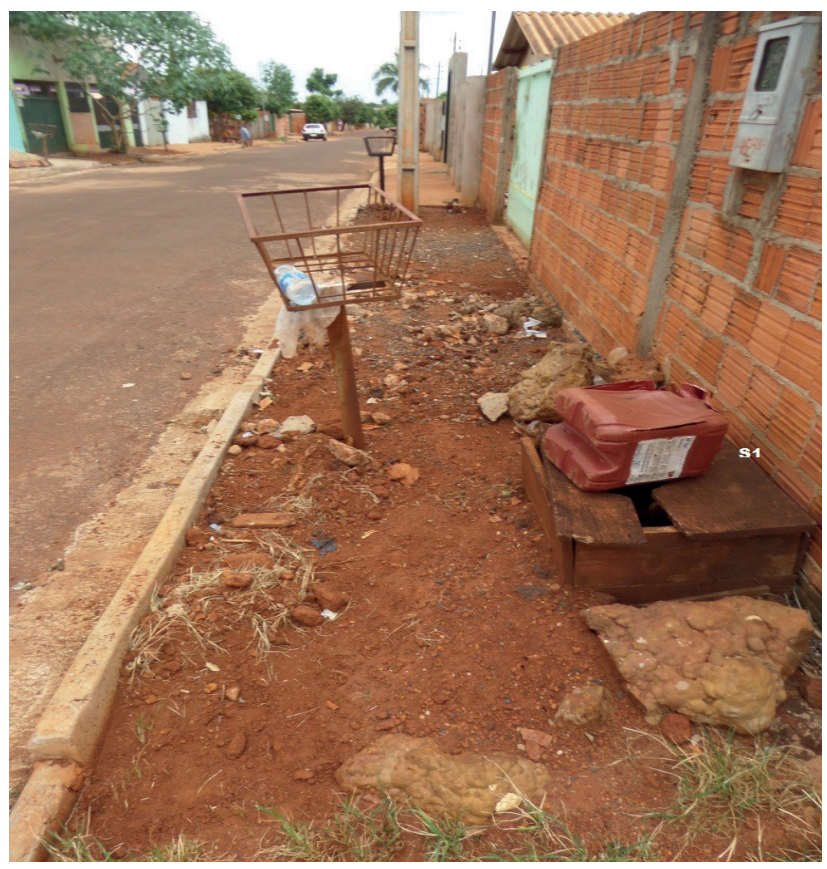

Source: The authors

In Figure 2, at a certain stage of the journey of S1, there is a post on the central axis of the sidewalk. At the left side, the free space corresponds to 0.28 centimeter, being that there is a trash can. Whereas on the right side, there are 0.81 free centimeters, which is insufficient to ensure accessibility and, therefore, is in disfavor with the municipal legislation in force.

The absence and/or discontinuity of sidewalks was noted in large part of paths (S1, S2, S4, S5, S7, S9, S10, S11, S12, S13, S15, S16, S18, S19), leading the pedestrian out of the sidewalk, sharing the same space with motorbikes and cars, putting them at risk of life.

${ }^{16}$ Study performed in Araguaína (TO) ratifies these findings, pointing out that problems on the sidewalks influence the occurrence of traffic accidents, particularly by a lack of understanding of the social issues that cross the society and ineffective surveillance .

The risk of accidents also increases when cyclists decide to ride on the sidewalk, leading the $\mathrm{PcD}$ for where there is 
no protection, predisposing them to imbalance and fall. The insufficient planning and maintenance of the sidewalks are also among the factors that increase this risk, making the paths as the only option, nor always the most secure and ideal ${ }^{17}$.

According to the level 8.8 of the NBR 90502, no vegetation should interfere with the movement of the pedestrians. However, it was found in one of the routes (S12), that one of the trees found in the central position of the sidewalks, has bifurcation of only $0.26 \mathrm{~cm}$, which reveals inappropriate afforestation.

Regarding the Session VII, of the Complementary Law no. 171 of 2012, which regulates the construction, renovation and maintenance of sidewalks of the city under study, the term afforestation refers to any plant cover in urban environments, public or private, which aims to improve the quality of life of citizens, guarantee of security, mobility and to the prevention of conflicts with the rest of the urban equipment, when used in the correct way ${ }^{18}$.

However, for these benefits to be gained, parameters and laws should be adopted and complied with, such as: noninterference in the public lighting; distance of at least five meters from the corner in order not to impair visibility; a distance of three meters of poles of lighting and six meters among themselves (in the absence of electrical network in the middle of the sidewalk); when there is electrical grid on the sidewalk, this number rises to eight meters; avoid afforestation on sidewalks with a width of less than 1.50 meters; prohibition of calcimine, painting, fixing nails, wires, advertisements, banners and other devices in the trunks of the trees; follow the guidelines of the Department of Environment, in relation to the type tree to be used, exemplifying, among other points ${ }^{18 .}$.

In addition to the public roads, other public spaces also have lack of accessibility, such as schools, universities and health services, which ends up increasing the needs of PcD and his or her family, passing from the motor to the emotional dimension. Not infrequently, health professionals demonstrate ease to establish ties with this clientele, however, reveal that there is a need for differentiated attention and integral care provision $^{19}$.

It is important to emphasize that there must be an awareness of professionals, especially the nursing team, causing the PcD to have a more active social involvement, in addition to being covered in its specificities through a humanized care ${ }^{20}$.

Although there is a commitment to overcoming the problems of urban and architectural, urbanistic and atitudinal part, there are still other forms of exclusion of $\mathrm{PcD}$, little visible in studies of this nature, such as the devaluation of gender issues. Women who have disabilities, sometimes do not correspond to a considerable number ${ }^{9}$ as observed in this study, commonly are not designed within their universes of social roles, and being reduced to vulnerable and childish subjects, suffer to gain their autonomy.
Figure 3 - Absence of sidewalk and afforestation affixed in the path from S2 to FHS. March 2016. Tangará da Serra, Mato Grosso State, Brazil

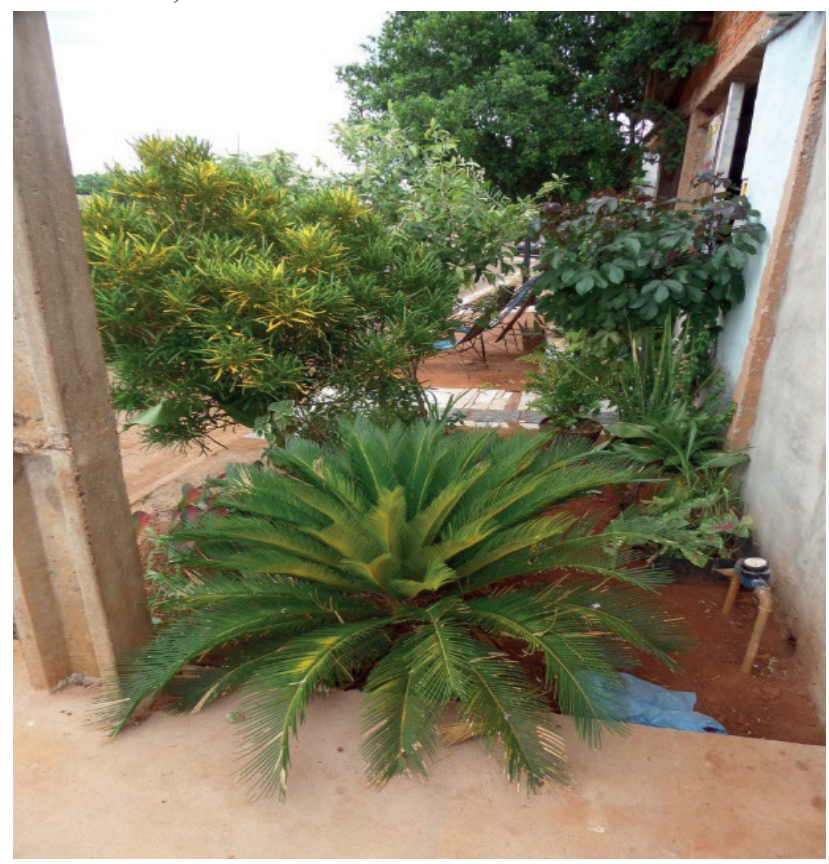

Source: The authors.

This reinforces the fact that accessibility is not limited to engineering, requesting especially for health professionals greater study and involvement, in order to empower and strengthen the discussions that contribute to new public policies.

\section{Conclusion}

From the study, it was found that the route of the residence from PcD to USF, has many obstacles that tend to derail the movement, especially wheelchair users. This fact provides the PcD tendency to lose their autonomy, seen that there is a need third parties helpo, which may be denied or by experiencing rejections throughout life, demonstrate to be afraid and not to request help. Thus, he or she will end up risking amid urban imperfections and irregularities found on their way and this trend will entail him or her new possibilities of damages. They can also opt for other routes with fewer barriers, but more distant and dangerous.

It is undeniable that the best way to reduce barriers is the movement of social inclusion, particularly in the planning of buildings and public mobility with greater accessibility, in the knowledge / reflection of the needs of the disabled person, support to families and articulation with the present social devices in the community. In addition, health professionals, especially nurses, play a key role in establishing links, so they can devise strategies to minimize such obstacles, while at the same time relieving moments of anguish and pain.

\section{References}

1. Amaral FLJS, Holanda CMA, Quirino MAB, Nascimento JPS, Neves RF, Ribeiro KSQS, et al. Acessibilidade de pessoas 
com deficiência ou restrição permanente de mobilidade ao SUS. Ciênc Saúde Coletiva 2012;17(7):1833-40. doi: http:// dx.doi.org/10.1590/S1413-81232012000700022.

2. Abnt NBR 9050: Acessibilidade a edificações, mobiliário, espaços e equipamentos urbanos. Rio de Janeiro: Associação Brasileira de Normas Técnicas; 2015.

3. Siqueira FCV, Facchini LA, Silveira DS, Piccini RX, Thuné E, Tomasi E. Barreiras arquitetônicas a idosos e portadores de deficiência física: um estudo epidemiológico da estrutura física das unidades básicas de saúde em sete estados do Brasil. Ciênc saúde Coletiva 2009;14(1):39-44.

4. Machado JN, Oliveira RFU, Silva RN. As condições de acessibilidade e adequação, para pacientes em cadeiras de rodas, em clínicas de fisioterapia na cidade de Goiânia. Goiânia: EdUCG; 2005.

5. Nascimento VF. Acessibilidade de deficientes físicos em uma Unidade de Saúde da Família. Rev Eletrônica Gest Saúde 2012;3(3):753-66.

6. Silva MGO, Lopes MI, Costa PVL. Fatores que interferem na realização do exame papanicolau em mulheres cadeirantes. Rev Interdisciplin 2014;7(4):99-105.

7. Rodrigues RC. Análise e tematização da imagem fotográfica. Cienc Inf 2007;36(3):67-76.

8. Lima SAV, Silva MRF, Carvalho EMF, Pessoa EAC, Brito ESV, Braga JPR. Elementos que influenciam o acesso à atenção primária na perspectiva dos profissionais e dos usuários de uma rede de serviços de saúde do Recife. Physis 2015;25(2):635-56. doi: http://dx.doi.org/10.1590/S010373312015000200016 .

9. Martins KP. Acessibilidade de pessoas com deficiência física e sensorial em unidades de saúde da família. João Pessoa: EdUFPB; 2015.

10. Silva DCN, Silva TC, Nogueira MS, Mendonça RMC, Valente PHF, Araújo RF, et al. Acessibilidade de portadores de deficiência física ou mobilidade reduzida na Unidade Básica de Saúde Jonas Manoel Dias em São Luís de Montes Belos - GO. Rev Fac Montes Belos 2015;8(3):36-60.

11. Moraes ARV, Dias ZLAL, Fernandes MA. Fatores sociais e adoecimento mental: relato de experiência em área de risco social. Rev Enferm UFPI 2014;3(4):101-5.

12. Serpa ABB. Acessibilidade para Pessoas com deficiência e inclusão social no turismo: a experiência da cidade de Socorro - SP. Brasília: EdUnB; 2009.

13. Almeida RB, Ferreira OM. Calçadas ecológicas: construção e benefícios sócio-ambientais. Goiânia; 2008. [acesso em 25 jun. 2018]. Disponível em: http://www. pucgoias.edu.br/ucg/prope/cpgss/ArquivosUpload/36/file/ CAL\%C3\%87ADAS\%20ECOL\%C3\%93GICAS.pdf

14. Freire Júnior RC, Arêas GPT, Arêas FZS, Barbosa LG. Estudo da acessibilidade de idosos ao centro da cidade de Caratinga, MG. Rev Bras Geriatr Gerontol 2013;16(3):541-58. doi: http://dx.doi.org/10.1590/S1809-98232013000300012.

15. Rodrigues LS. Acessibilidade em praças públicas: estudo de caso no município de Formiga - MG. Formiga: EdUNIFOR; 2014.

16. Nascimento JL, Pereira AJ, Ribeiro RS. Um estudo sobre as irregularidades no trânsito em Araguaína (TO) e a grande ocorrência de acidentes na área urbana da cidade. Rev Tocantinense Geog 2013; 2(3):1-15.

17. Barbosa ADP, Theobald R. Caminhabilidade do trabalhador portador de mobilidade reduzida nas calçadas da cidade de Aracaju: uma análise das áreas centrais e suas possíveis consequências de acidente de trajeto. Ideias Inov 2016;3(1):11-22.

18. Tangará da Serra. Prefeitura Municipal de Tangará da Serra. Lei complementar $n^{\circ} 171$, de 05 de dezembro de 2012. [acesso em 25 jun. 2018]. Disponível em: http://www.tangaradaserra. mt.gov.br/fotos_downloads/18112.pdf.

19. Dantas TRA, Gomes TM, Costa TF, Azevedo TR, Brito SS, Costa KNFM. Comunicação entre a equipe de enfermagem e pessoas com deficiência auditiva. Rev Enferm UERJ 2014; 22(2):169-74. doi: 10.9789/2175-5361.2014.v6i4.1695-1706

20. Martins KP, Costa KNFM, Rezende LCM, Gomes TM, Dantas TRA, Santos SR. Percepção da equipe de enfermagem acerca da acessibilidade física e de comunicação de pessoas com deficiência visual. Ciênc Cuid Saúde 2015;14(2):1019-26. doi: http://dx.doi.org/10.4025/cienccuidsaude.v14i2.22045 